\title{
FORECASTING OF APPLE PRODUCTION IN THE REPUBLIC OF SRPSKA
}

\section{Miroslav Nedeljković1, Velibor Potrebić}

\begin{abstract}
The main paper goal is to create an adequate trend model by applying a quantitative research method, i.e. trend analysis that will enable prediction of apple production in the Republic of Srpska for a three-year period (2019-2021). Trend analysis involved the use of linear, quadratic and exponential trend models. Prediction is based on data time series for the period 1998-2018. Gained results show that although the unstable production it could be expected the growth of total production and number of apple trees, while apple yields are expected to decline in the observed period. Obtained results can serve for strategic approach in further development of this sector of fruit production.
\end{abstract}

Key words: forecasting, analysis, apple production, Republic of Srpska.

JEL $^{3}:$ C53, Q10

\section{Introduction}

The apple belongs to the group of roses, where this fruit is produced the most worldwide (Ntakyo et al., 2013). There are over than 7,500 varieties of apples. Among the most recognized are Red Delicious, Golden Delicious, Fuji, Jonagold, etc. (Wu et al., 2016). The great ability to adapt to different natural conditions and high fruits' quality ensured to apple important position in fruit production (Užar et al., 2019). Human alimentation recognizes apple as fruit with expressed nutritional and medicinal characteristics, that could be used as fresh or processed (Jeločnik et al., 2019). Technology of its production is complex, labour and input intensive, requiring large investments. On the other side, it represents a highly accumulative production (Gvozdenović, 1998).

According to FAO (2020), in 2018 apple was produced globally at 4,904,305 ha, while its volume of production was reached 86,142,197 tons. According to same

1 Miroslav Nedeljković, Ph.D., Assistant Professor, University „Bijeljina“, Faculty of Agriculture, Pavlovića put bb, 76300 Bijeljina, BiH, Phone: +387 66893 935, E-mail: miroslavnedeljkovic2015@gmail.com

2 Velibor Potrebić, M.A., Institute of Agricultural Economics, Volgina Street no. 15, 11060 Belgrade, Serbia, Phone: +381 116972 858, E-mail: velibor.potrebic@gmail.com

3 Article info: Original Article, Received: 19 $9^{\text {th }}$ June 2020, Accepted: $29^{\text {th }}$ June 2020. 
source, almost the 2/3 of global apple production is organized in Asia (62.1\%), whereas the greatest producer could be labelled China with the production of over the 39.2 million tons. Among the largest European producers could be marked Poland (almost 4 million tons), Turkey (3.6 million tons), Italy (2.4 million tons) and France (1.7 million tons).

By its representation, apples are the second ranked fruit species in the Republic of Srpska (right after the plums). According to data of the Statistical Office of the Republic of Srpska the apple production in 2018 was 68,993 tons, what represents $61 \%$ of total apple production in the Bosnia and Herzegovina. Considering the production potential of apples, the analysis and the prediction of its production is gaining in importance. In their previous researches some authors were involved in analysis of apple production (Maksimović, 2012; Keserović et al., 2014; Vlahović et al., 2015; Milić et al., 2016). Užar and associates (2019) have been analysed parameters of apple production in the Republic of Serbia and the Republic of Srpska for the period 2006-2017. Based on the trend model, authors predicted indicators of apple production for the period 2018-2020. In line to performed analysis, it can be expected the increase in apple production in both observed countries.

According to Novković and associates (2010), analysis of historical data and prediction might be based on the arranged series of data in equal time intervals, i.e. by the analysis of time series of observed phenomenon. In the conditions of market economy, successful production depends on the monitoring, analysis, and prediction of the production results and key factors which influence the production (Mutavdžić, 2010).

In line to above mentioned, the subject of this article is the analysis of the production trend in the Republic of Srpska, in order to create the proper prediction model for the production parameters of the apple. The importance of conducted research could be in reconsidering of gained results in process of strategic decision making regarding the development of this fruit production.

\section{Used methodology and data sources}

In addition to the standard methods of descriptive statistics (average, interval of variation, coefficient of variation, and rate of change) research requires analysis of linear, quadratic and exponential trend models.

Model of linear trend assumes the use of next formula:

$$
Y t=\beta_{0}+\beta_{1} t+e_{t}
$$


Model of quadratic trend was linked to following formula:

$$
Y t=\beta_{0}+\beta_{1} \times t+\beta_{2} t^{2}+e_{t}
$$

Model exponential trend is represented by next formula:

$$
Y t=\beta_{0} \times \beta^{t}{ }_{1} \times e_{t}
$$

Selection of adequate prediction model is based on three measures of accuracy: Mean absolute percentage error (MAPE), Mean absolute deviation (MAD) and Mean square deviation (MSD), (Goodwin, Lawton, 1999; Makridakis, Hibon, 2000).

MAPE (eng. Mean Absolute Percentage Error) is a method of prediction used in time series where periodicity is particularly observed. It's determined by the next formula:

$$
\text { MAPE }=\frac{1}{n} \sum \mathrm{I}(\mathrm{yt}-\hat{\mathrm{y}} \mathrm{t}) / \mathrm{yt} \mathrm{I} 100
$$

MAD (eng. Mean Absolute Deviation) represents a dispersion method that is created as a deviation of the modality from the representative parameter. It's described by the following formula:

$$
\mathrm{MAD}=\frac{1}{n} \sum \mathrm{Iyt}-\hat{\mathrm{ytI}}
$$

MSD (eng. Mean Squared Deviation) represents the mathematical expectation of how well the arithmetic mean fits to gained results. It's defined by the following formula:

$$
\operatorname{MSD}=\frac{1}{n} \sum(\mathrm{yt}-\hat{\mathrm{yt}})^{2}
$$

The lowest value of previously presented accuracy measures is a good indicator for adequate selection of the model that cause the minimal errors in prediction (Karim et al., 2010).

The source of used data for apple production (for the period 1998-2018) represents the annual reports for the sector of agriculture of the Statistical Office of the Republic of Srpska. Data processing was done in the statistical software package "MINITAB 17.1". 


\section{Research results with discussion}

By the insight into the basic parameters of apple production for the observed period it could be seen that there were in average 2,330 trees. Their trend showed certain level of instability in the analysed period $(\mathrm{CV}=35.59 \%)$. Similar instability of trend was also shown at apple production $(\mathrm{CV}=31.97 \%)$, whose average value was 36,347 tons. Average apple yield $(16.47 \mathrm{~kg} /$ three $)$ is the only parameter that showed a negative trend within the analysed period $(\mathrm{r}=-1.57 \%)$. On the other side, its trend was slightly more stable than the other two production indicators $(\mathrm{CV}=26,3 \%)$, (Table 1.).

Table 1. Dynamics of apple production in the Republic of Srpska (1998-2018)

\begin{tabular}{|c|c|c|c|c|c|}
\hline \multirow{2}{*}{$\begin{array}{c}\text { Production } \\
\text { parameters }\end{array}$} & \multirow{2}{*}{ Average } & \multicolumn{2}{|c|}{ Interval of variation } & Coef. of variation & Rate of change \\
\cline { 3 - 4 } & & Min. & Max. & (\%) & (\%) \\
\hline Trees (pcs.) & 2.330 & 1.329 & 3.690 & 35,59 & 5,24 \\
\hline Production $(\mathrm{t})$ & $36.347,76$ & 20.278 & 68.993 & 31,97 & 3,63 \\
\hline Yield $(\mathrm{kg} / \mathrm{three})$ & 16,47 & 7,90 & 25,50 & 26,33 & $-1,57$ \\
\hline
\end{tabular}

Source: Calculation according to SORS, 2020.

In next graph (Graph 1.) is presented the trend of apple trees within the observed period. With blue is marked the trend of the actual number of the fruit threes. By red are marked the assigned values, while with green are marked the predicted values for the observed production parameter until 2021.

Graph 1. Trend of apple trees number

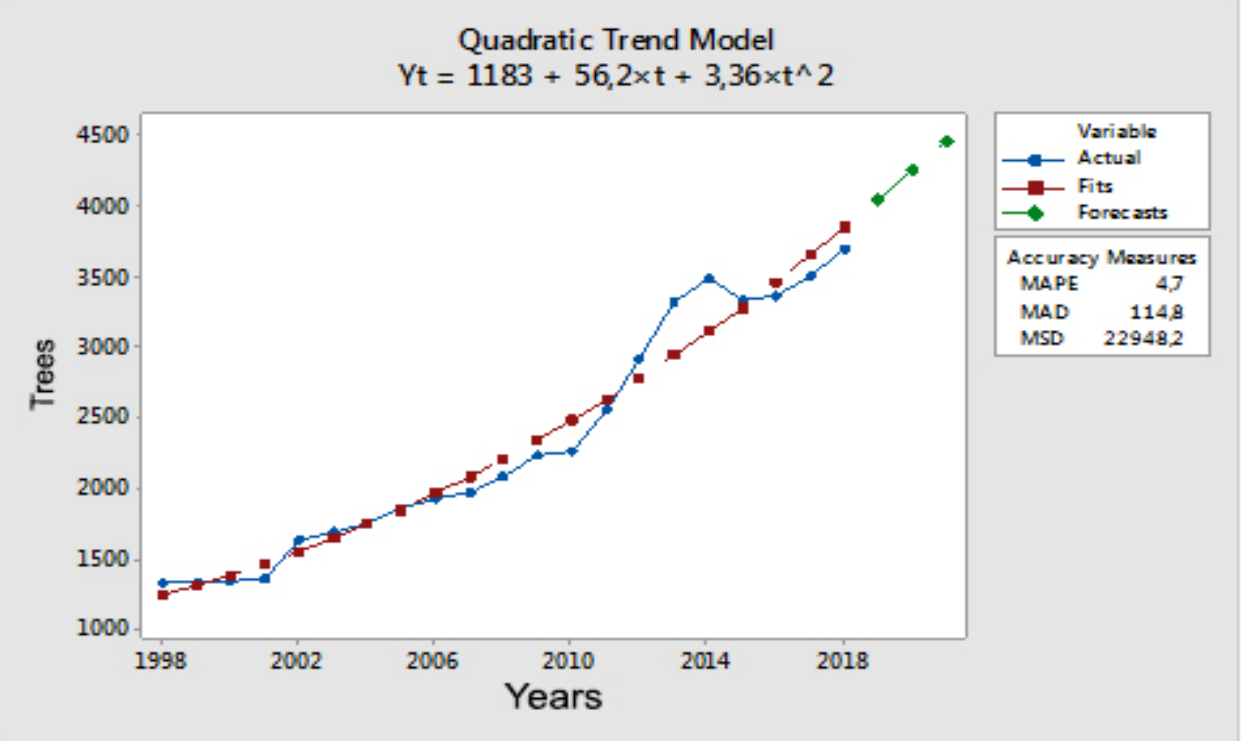

Source: According to authors' calculation. 
In order to select the adequate model for predicting the number of apple trees in next three years, the calculation and analysis of the accuracy measures for the three trend models were done. It was noticed that the quadratic trend model fits the best (has the lowest values), (Table 2.).

Table 2. Measures of accuracy

\begin{tabular}{|l|c|c|c|}
\hline \multirow{2}{*}{\multicolumn{1}{c|}{ Trend model }} & \multicolumn{3}{c|}{ Criterions } \\
\cline { 2 - 4 } & MAPE & MAD & MSD \\
\hline Linear & 7,0 & 148,0 & 34974,6 \\
\hline Exponential & 4,7 & 116,5 & 24834,4 \\
\hline Quadratic & 4,7 & 114,8 & 22948,2 \\
\hline
\end{tabular}

Source: According to authors' calculation.

In the following three-year period, a constant increase in the number of apple trees is expected. So in the last year of the prediction period their number will reach the 4,465 threes, i.e. for 775 threes more than the maximum reached in analysed period (Table 3.).

Table 3. Apple threes forecasting

\begin{tabular}{|c|c|}
\hline Forecast period & Number of apple threes \\
\hline 2019 & 4.044 \\
\hline 2020 & 4.251 \\
\hline 2021 & 4.465 \\
\hline
\end{tabular}

Source: According to authors' calculation.

At Graph 2. could be seen the trend of apple production with its actual, given and forecasted values. 
Graph 2. Trend of apple production

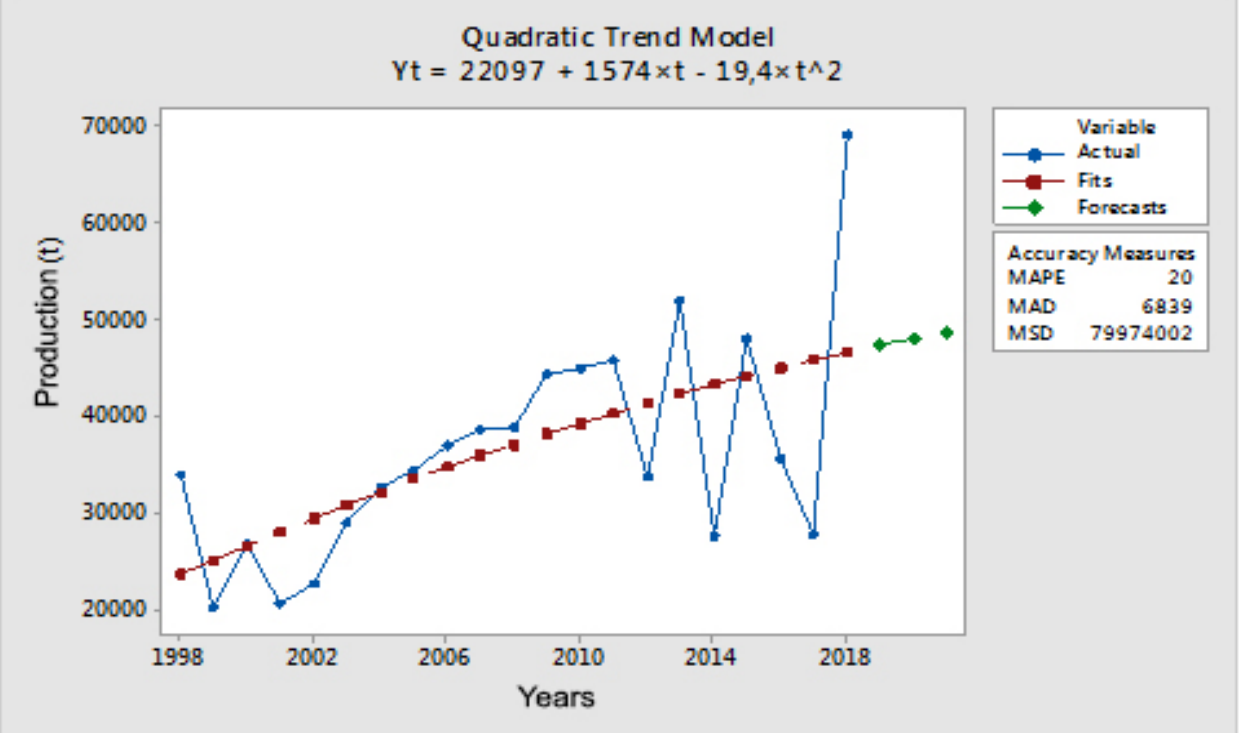

Source: According to authors' calculation.

From the Table 4. it can be seen that the model of quadratic trend is the most convenient for prediction of apple production in the following tree-year period.

Table 4. Measures of accuracy

\begin{tabular}{|l|c|c|c|}
\hline \multirow{2}{*}{\multicolumn{1}{c|}{ Trend model }} & \multicolumn{3}{c|}{ Criterions } \\
\cline { 2 - 4 } & MAPE & MAD & MSD \\
\hline Linear & 21 & 7044 & 80376677 \\
\hline Exponential & 21 & 7437 & 82565098 \\
\hline Quadratic & 20 & 6839 & 79974002 \\
\hline
\end{tabular}

Source: According to authors' calculation.

Prediction for the period 2019-2021. shows the expecting increase in apple production. In the last year of the forecast period, the apple production will be over 48,684 tons, what is for 12,337 tons more than the average production, or for 20,308 tons less than the maximally achieved production in the analysed period (Table 5.).

Table 5. Apple production forecasting

\begin{tabular}{|c|c|}
\hline Forecast period & Apple production (t) \\
\hline 2019 & $47.323,5$ \\
\hline 2020 & $48.023,6$ \\
\hline 2021 & $48.684,8$ \\
\hline
\end{tabular}

Source: According to authors' calculation. 
Graph 3. Trend of apple yields

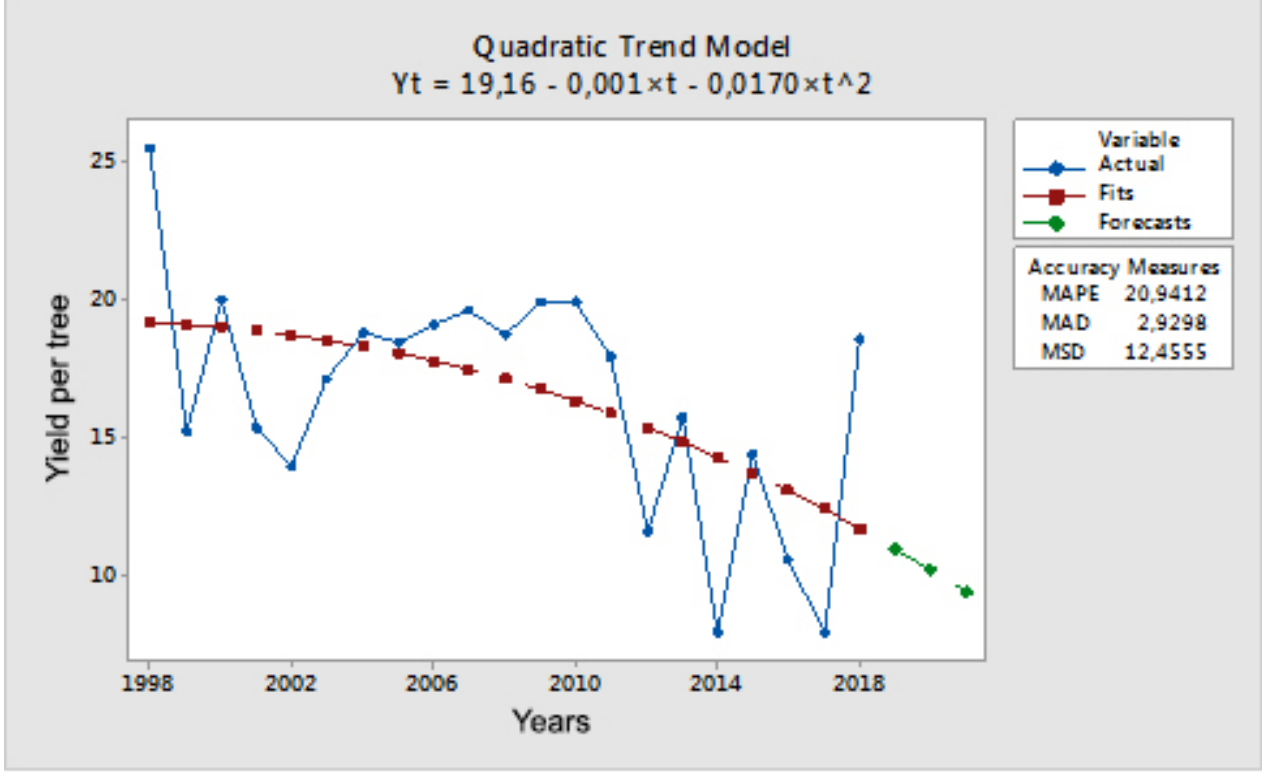

Source: According to authors' calculation.

By previous graph (Graph 3.) was presented the trend of apple yields in the observed period and the forecast (three-year) period.

By the use of previously calculated accuracy measures (MAPE, MAD and MSD), (Table 6.) it could be seen that quadratic trend model gains again the lowest values, so it's used in further forecasting of apple yields.

Table 6. Measures of accuracy

\begin{tabular}{|l|c|c|c|}
\hline \multirow{2}{*}{\multicolumn{1}{c|}{ Trend model }} & \multicolumn{3}{c|}{ Criterions } \\
\cline { 2 - 4 } & MAPE & MAD & MSD \\
\hline Linear & 22,1587 & 3,0830 & 12,7640 \\
\hline Exponential & 22,3555 & 3,2366 & 13,2688 \\
\hline Quadratic & 20,9412 & 2,9298 & 12,4555 \\
\hline
\end{tabular}

Source: According to authors' calculation.

Gained results for apple yields forecasting for the period 2019-2021 show that it come to decrease in parameter value. So, apple yields in 2021 would be at the level of $9,35 \mathrm{~kg} /$ three, what is far less than the achieved average yields or just for $1,45 \mathrm{~kg} /$ three more than the minimal yield achieved in observed period (19982018), (Table 7.). 
Table 7. Apple yields forecasting

\begin{tabular}{|c|c|}
\hline Forecast period & Apple yields (kg/three) \\
\hline 2019 & 10,91 \\
\hline 2020 & 10,15 \\
\hline 2021 & 9,35 \\
\hline
\end{tabular}

Source: According to authors' calculation.

\section{Conclusion}

In line to previously gained results, next conclusions could be derived:

- Apple is the important fruit species in Republic of Srpska;

- Highly unstable trend in analysed period have apple trees and apple production;

- In upcoming period it could be expected continuous increase in number of apple threes, up to the level of 4,465 threes;

- Apple production will increase in forecast period, having at the end of this period the higher values than the average value for the analysed long-term period (486,894 tons);

- Contrary to production, apple yields are showing decrease tendency both in analysed forecast and observed long-term period (1998-2018), while expressing much lower values in forecast period than the average yields $(9.35 \mathrm{~kg} /$ three $)$.

According to increase in apple production in the Republic of Srpska, in the upcoming period some additional improvements within the observed branch of fruit growing have to be done, primarily in terms of further yields growth, introduction of new varieties, and searching for new market opportunities that would justify the quantities produced at the national level.

\section{References}

1. FAO (2020). Global apple production, portal of the FAO, Rome, Italy, retrieved at: www.fao.org/faostat/en/\#data/QC, 15 May 2020.

2. Goodwin, P., Lawton, R. (1999). On the asymmetry of the symmetric MAPE. International Journal of Forecasting, (15)4:405-408.

3. Gvozdenović, D. (1998). Jabuka. Faculty of Agriculture, Novi Sad, Serbia.

4. Jeločnik, M., Subić, J., Kovačević, V. (2019). Competitiveness of apple processing. Ekonomika, 65(4):41-51. 
5. Karim, R., Awala, A., Akhter, M. (2010). Forecasting of Wheat Production in Bangladesh, Bangladesh Journal of Agricultural Research, 35(1):17-28.

6. Keserović, Z., Magazin, N., Kurjakov, A., Dorić, M., Gošić, J. (2014). Poljoprivreda u Republici Srbiji - Voćarstvo, Statistical Office of the Republic of Serbia, Belgrade, Serbia.

7. Makridakis, S., Hibon, M. (2000). The M-3-Competition: Results, conclusions and implications. International Journal of Forecasting, 16(4):451-476.

8. Maksimović, B. (2012). Primena marketing koncepcije u funkciji unapređenja uvoza voća i prerađevina iz Republike Srbije. Dissertation, Faculty of economics, University in Novi Sad, Subotica, Serbia.

9. Milić, D., Lukač Bulatović, M., Vučičević, V. (2016). Tendencije kretanja površina i proizvodnje voća u Vojvodini. Agoekonomika 45(71):57-66.

10.Mutavdžić, B. (2010). Analiza i predviđanje proizvodno-ekonomskih parametara $u$ poljoprivredi Vojvodine. Dissertation, University in Belgrade, Faculty of Agriculture, Belgrade, Serbia.

11.Novković, N., Mutavdžić, B., Šomođi, Š. (2010). Modeli za predviđanje u povrtarstvu, Visoka poslovna škola strukovnih studija, Škola biznisa, 3(2010):4149.

12.Ntakyo, P. R., Mugisha, J., Elepu, G. (2013). Socio-Economic Factors Affecting Apple Production in Southwestern Uganda. African Crop Science Journal, 21(4):311-321.

13.SORS (2019). Apple production - main facts, Bulletin - Agriculture, Statistical Office of the Republic of Srpska, Banja Luka, BiH.

14.Užar, D., Tekić, D., Mutavdžić, B. (2019). Analiza i predviđanje proizvodnje jabuke u Republici Srbiji i Bosni i Hercegovini. Ekonomija, teorija i praksa, 12(4):1-10.

15.Vlahović, B., Puškarić, A., Veličković, S. (2015). Izvoz jabuke iz Republike Srbije: Stanje i tendencije. Agroekonomika, 44(65):10-21.

16.Wu, X., Wu, B., Sun, J., Ya, N. (2016). Classification of Apple Varieties Using Near Infrared Reflectance Spectroscopy and Fuzzy Discriminant C-Means Clustering Model. Journal of Food Process Engineering, 40(2):1-7, doi: 10.1111/jfpe.12355 